November 30, 2009

\title{
The Economic Effects of Bus Transit in Small Cities
}

Dagney Faulk, Ph.D.* (contact)

Michael Hicks, Ph.D.

Center for Business and Economic Research

Miller College of Business

Ball State University

Muncie, IN

*(765)285-5152

dgfaulk@bsu.edu 


\title{
The Economic Effects of Bus Transit in Small Cities
}

\begin{abstract}
This research investigates how public transit affects economic outcomes in counties with small to medium-sized cities. Our objectives are to answer: Do counties with bus transit have lower growth in transfer payments such as food stamps, Temporary Aid to Needy Families (TANF), or higher income growth, employment growth, and population growth? Public transit is commonly viewed as a social service; this analysis explores the economic impact of this public investment. We find that relative to counties without bus transit, counties with bus systems have significantly lower unemployment rates, lower growth in family assistance, lower growth in food stamp payments, and higher population and employment growth. Yet the poverty rate is higher in counties with bus transit systems and the effect on income is ambiguous. The positive impact on job access which reduces payments for family assistance and food stamps is tempered by lack of discernable effects on income likely driven by supply side effects in the labor market.
\end{abstract}

Keywords: Employment, Transit, Bus, Spatial Mismatch

JEL Classification: R42 - Government and Private Investment Analysis; R58 - Regional Development Policy; H54 - Infrastructures; Other Public Investment and Capital Stock; R11 Regional Economic Activity: Growth, Development, and Changes; R49 Transportation Systems - Other 


\section{INTRODUCTION}

For individuals, particularly low income individuals, access to transportation may determine the number and types of available jobs and ultimately income levels. The spatial mismatch hypothesis suggests that geographic racial (and income) segregation is a primary determinant of unemployment and poverty, particularly for minorities. The residential location of available workers is often far from the location of available jobs which results in relatively high commuting costs associated with moving low-income workers between residential areas and job opportunities (Kain 1968).

Much of the research related to the spatial mismatch hypothesis has focused on large metropolitan areas. While smaller cities exhibit patterns of racial and/or income segregation in residential areas, the smaller size of these cities may mean that jobs are more accessible. Ihlanfeldt and Sjoquist (1990) show that spatial mismatch is more pronounced in larger metro areas and that this theory explains 14 percent of the employment gap for youths in medium-sized cities versus 25 percent in large cities. This finding suggests that access to transportation will have a differential impact in cities of different sizes. Despite the longstanding interest in this issue, little research has explicitly examined the relationship between transit and economic outcomes in small and medium-sized cities.

This paper uses a carefully constructed datasets of counties with small to medium-sized cities in the upper Midwest (Illinois, Indiana, Michigan, Ohio, Pennsylvania, and Wisconsin) to examine the relationship between transportation, particularly bus transit, and various measures of economic development. ${ }^{1}$ Of the counties in the dataset, 39 had a bus system in 2006 . The presence and absence of public transit in counties of this size provides a natural experiment to examine the impact of public transit. Of the counties included in this study, transit is primarily 
bus and demand response. Demand response (commonly called Dial-a-ride or DR) is transit that does not operate on a fixed route like the most common type of bus service. DR consists of passenger cars, vans, or small buses responding to calls to agencies that for the most part are publicly funded and may or may not provide other types of public transportation. The focus of our analysis is fixed-route bus transit since this type of transportation is available to any user who can pay the fare. In contrast, demand response service is often limited service to the elderly or people with disabilities.

Since the early 1970s, federal, state and local governments have invested in public transit systems. ${ }^{2}$ In 2006 federal, state and local governments provided just over \$27 billion in capital and operating funds to public transit systems in the U.S. (33.9 percent of transit expenditures were from local government). ${ }^{3}$ Public transit systems are highly subsidized (although to a lesser degree than federal highways). The federal government generally funds 80 percent of capital expenditures with a 20 percent local match, and only a small portion of capital and operating funds is generated by the transit system primarily through fares, advertising fees, and taxes imposed by the transit authority or revenue from a municipality's general fund. ${ }^{4}$

More generally, the literature on infrastructure investment has shown that at the national level, investment in infrastructure capital is positively related to productivity growth. See Gramlich (1994) for a review essay. Hicks (2006) provides a recent study. Public transit infrastructure is one component of infrastructure capital.

The contribution of the current research is to determine if and how public transit is related to key labor market variables, measures of socio-economic wellbeing, and economic development in counties with small cities. The remainder of the paper is organized as follows. The next section provides a review of the literature related to the economic development impact 
of public transit systems. The third section provides a brief description of transit funding and usage in the cities considered in this analysis. The fourth section provides an overview of the data used in the analysis. The fifth section describes our modeling strategy. The penultimate section discusses results. The final section offers a summary and conclusions.

\section{THE LITERATURE}

Much of the literature examining the relationship between transit and economic development has focused on highways or rail transit. Few studies have examined the effects of the availability of fixed-route bus transit on economic development or various socioeconomic indicators related to labor markets or antipoverty expenditures. In his review of public transportation policies from 1960 to 2000, Sanchez (2008) concludes that we know little about the effect that public transportation policies have on "creating opportunity or improving the wellbeing of families in the grip of poverty” (840). We provide a review of the more general literature on mass transit and economic development and the literature addressing the impact of transit for the low income population. These two themes should be related in that if transit has a positive impact on traditional economic development indicators, the low income population should receive some benefit. 


\subsection{Transit and Economic Development}

The studies examining the relationship between transit and economic development have focused primarily on fixed rail transit systems in large cities. Bollinger and Ihlanfeldt (1997) find that while the presence of a MARTA station had no impact of employment or earnings in the area around the station, it did alter the composition of employment increasing government employment proximate to stations.

There are a variety of studies looking at the relationship between rail stations and property values. One of the most rigorous is Bowes and Ihlanfeldt (2001) which examines the effect of proximity to rail stations on residential property values in Atlanta and find that residential properties within a quarter mile of a station sell for 19 percent less than properties three miles from a station indicating that there are negative externalities associated with proximity to the station. Properties between one and three miles have a higher value than those further away indicating a positive benefit from being close but not too close to rail transit. This is the traditional inverted U-shaped proximity relationship observed in hedonic pricing models which account for proximity effects.

The one study that we are aware of that examines buses and economic development focuses on property values. Rodriguez and Targa (2004) examine the effect of Bus Rapid Transit (BRT) on property value in Bogota Columbia and find that property rental prices decrease by 6.8 to 9.3 percent for each 5 minute increase in walking time to the BRT corridor which suggests that BRT positively influences property values.

The impact of rail stations on commercial development has been investigated for San Francisco’s BART (Cervero and Landis 1997), Atlanta’s MARTA (Bollinger and Ihlanfeldt 1997, Bowes and Ihlanfeldt 2001), and Washington, D.C.’s METRO (Green and James 1993). 
The BART and METRO studies compare commercial activity in station and nonstation areas before and after station openings and do not control for other influences. The BART study finds a small effect of rail on commercial activities and the METRO study finds large effects. Bollinger and Ihlanfeldt (1997) include extensive controls and find that rail stations have no effect on commercial activity. Bowes and Ihlanfeldt (2001) focus exclusively on retail activity and find that rail stations further from the CBD have a positive effect on retail activity with the largest effects occurring within a quarter and half mile from the station.

A variety of studies have also looked at infrastructure, particularly roads and economic development. Wasylenko (1997) provides a key review of findings, as does Fox and Porca (2001), with the latter focusing on rural growth and the former reviewing the broad literature. A variety of empirical studies have addressed this issue. Bollinger and Ihlanfeldt (2003) examine a variety of tax incentive programs and investment in transportation infrastructure and find that highway improvements increase the employment share at the census tract level while investment in rail stations did not. Dalenburg, Partridge and Rickman (1998) found that investment in public highways and other public capital has a positive impact on state employment growth. Other empirical studies include Holtz-Eakin (1994), Eberts (1991) and Fox and Murray (1990).

\subsection{Transit and Employment Outcomes}

There are a variety of studies examining the relationship between individual's access to transportation and employment outcomes. Car ownership has been shown to positively influence employment (Baum 2009, Ong 2002, Raphael and Rice 2002) although the later study also showed that car ownership has a negative effect on wages within the same sample. The negative effect on wages may be attributed to not controlling for urban versus rural labor markets. Gurley and Bruce (2005) examine vehicle access (a broader measure than ownership) and control for 
urban and rural differences and find that car access positively effects employment, hours worked, and pay level.

The studies examining employment outcomes and other types of transit have focused on job accessibility. These studies use different geographic areas, different statistical methods, and focus on different groups of employees and find differing effects. Sanchez, Shen and Peng (2004) and Bania, Leete and Coulton (2008) show that access to transit, including bus transit in the later study, has no affect on employment outcomes. In contrast, Sanchez (1999) finds that access to public transit leads to higher labor force participation in Portland, OR and Atlanta, GA. Allard and Danziger (2003) and Ong and Blumenberg (1998) do not use specific transit measures but find that proximity to jobs positively affect employment outcomes.

In sum, studies examining the economic development effects of transit and studies examining the impact of transit on employment outcomes have focused on large cities and have found limited effects. There are likely to be differences in results for cities of different sizes. In their analysis of metropolitan areas of different sizes, Partridge and Rickman (2008) find a differential impact of job growth on poverty -- in smaller metropolitan areas job growth has a larger effect on reducing poverty than in larger metro areas. Jobs are likely to be more accessible in smaller cities and the economic development impact of bus transit is likely to be more diffuse than that of fixed-route rail.

\section{BRIEF OVERVIEW OF TRANSIT IN SMALL MIDWESTERN CITIES}

Exhibits 1-4 show various characteristics of the transit systems for the counties with bus systems in our sample. Exhibit 1 shows that the level of real total capital funding for all public transit in these counties (this includes bus, demand response, light rail, and ferry boat) was somewhat variable although the overall trend was an increase from \$1.98 million in 1992 to over 
\$8.85 million in 2006 with a peak of \$14.2 million in 2002 (in 1982-84 constant dollars). The federal government provided the largest share of capital funding. As shown in Exhibit 2, real operating expenditures for bus systems increased from \$48.46 million in 1992 to $\$ 71.1$ million (46.6 percent) in 2006. Capital expenditures on rolling stock (buses) and related facilities was more variable but increased from \$7.67 million in 1992 to \$11.1 million in 2006 .

[Exhibits 1 and 2 about here.]

Exhibits 3 and 4 focus on capacity and usage of transit systems in the counties with bus systems included in the study. Since the mid 1990s the number of buses both directly operated and contracted out for traditional fixed route bus systems have increased steadily from 805 in 1992 to 1,030 in 2006 (28 percent). The general trend in bus usage has been positive although there is a visible variability. Over this period unlinked bus passenger trips increased from 37.6 million to 49.7 million (32 percent), and passenger miles traveled increased from 115 million to 159.1 million (38 percent).

[Exhibits 3 and 4 about here.]

\section{DATA AND SAMPLING METHOD}

We investigate the role public transit in small cities plays in changes to patterns of transfer payments and improving worker outcomes. Panel data from 1992-2006 is used to analyze the proposed research questions. We examine the economic impact of transit in terms of traditional and nontraditional variables. Variables traditionally used to measure economic development include population, employment and income growth. Nontraditional variables include poverty rates, unemployment rates, and federal transfer payments. We use these latter variables to draw conclusions about the effects of transit investment on low-income populations. 
We use three control groups to examine the economic effects of bus transit. The rationale behind using three control groups is to ensure that our results are robust. There is some overlap among the counties in each control group. The first control group is constructed using propensity score matching. The propensity score matching model uses 1970 county characteristics to estimate the influence of specific factors on the probability that a county will have bus transit. The propensity score estimates the likelihood that any county will have bus transit based on the characteristics of tracts that actually have transit. Matching counties based on the likelihood that they have bus transit should control for the factors that predisposed particular counties to have bus transit. Using this method, each county with transit is match to the county with the nearest propensity score that does not have transit.

The second control group is constructed using a non-equivalent group design (NEG) of the type presented by Reed and Rogers (2003) and Hicks (2003). In these papers univarate comparisons between the treatment and control groups are performed. We extended this approach by including a multivariate scoring process on both concurrent and pre-test periods. Our intent was to minimize the internal threat to validity of the selection by including a time period prior to federal subsidization of municipal bus service. In this approach we selected a control sample by scoring all non-treatment regions on most proximal personal income, per capita income, total employment and growth in each of these variables (from 1970 to 2008). Each county was scored on each attribute and a control sample selected from the highest scoring $n$ counties. These counties qualified for inclusion into the NEG as they demonstrated the most similar set of economic characteristics from a period extending more than a decade prior to through the end of the sample period. 
The third control group was constructed using two criteria: (1) counties with population between 50,000 and 125,000 inhabitants in 1950 in the six aforementioned states and (2) counties with cities with boundaries primarily in one county. This selection criterion was based upon a larger regional analysis initiative in small urban areas within the Great Lakes region. We call this the Like City method.

Table 1 shows the definitions and sources of the variables that we use in the model. Descriptive statistics for the total sample, counties with bus systems, the six counties that started bus systems between 1992 and 2006, and counties without bus systems for each sampling method are shown in table 2. The counties with bus systems are the same for each sampling method. The control group (counties without bus systems) is different.

Of the counties included in the sample, 46 percent had bus systems during this period. ${ }^{5}$ Many of the variables that we consider are more favorable in the counties with bus systems. Average real income growth, per capita income growth, population growth and employment growth are larger in these counties, but the variation is also greater compared to counties without bus systems. The unemployment rate is lower in counties with bus systems. The descriptive statistics show that average family assistance payments per capita declined over this period. The decline was greater in counties with bus systems relative to counties without bus systems. Growth in average real food stamps per capita was higher, and the decline in average real family assistance was larger. In contrast per capita food stamp payments increased in counties with bus systems and decreased in counties without bus systems.

[Table 1 and 2 about here] 


\section{MODELING STRATEGY}

Assessing transportation infrastructure’s impact on regional economic activity imposes significant modeling concerns related to the endogeneity of the investment. More rapidly growing cities, and those with greater fiscal resources may be more likely to pursue infrastructure investment. This raises the specter of endogeneity bias in subsequent econometric estimates. This problem is not limited to transportation infrastructure, and indeed may be more of a concern in areas such as firm entrance and expansion, for example. In the context of transit we imagine two types of bias inducing specification concerns. First, it is possible that a critical variable may be omitted from the model. For example, the key determinant of receipt of federal transportation infrastructure funding may be through an earmark process, not a formulary. Thus, the tenure or committee assignment of the region's Senator or Representative may be more predictive of transit funding than other factors. Failure to account for this in the model specification raises the specter of omitted variable bias. Second, regional growth may matter in the federal transit funding. If transit dollars are allocated more disproportionately based upon growth, poverty or demographic characteristics, then endogeneity in transit funding may bias the coefficients of the model.

There is the potential for endogeneity bias with the provision of public transit. As mentioned above most of the capital funding for public transit is from the federal government, but there must be a local match to qualify for federal funding, and operating funds (staff salaries) must come from local sources. There may be differences among cities that cause some cities to be more likely to apply for federal transit funding than others or that cause some cities to be more willing to fund the local match and a portion of operating funds. The likelihood of applying for federal transit funding may be related to differences in human capital, local 
government efficiency, or political enthusiasm for these types of intergovernmental transfer. This suggests that a systematic and careful examination of potential endogeneity is warranted.

Within the literature there are two methods for dealing with the endogeneity concern. The more common and earlier method is a simultaneous equation approach employing elements of a production function. This technique is attractive since it imposes some theoretical basis for the interpretation of the relationships and the resulting estimates. This method has three significant limitations beyond the appropriate structuring of the production function relationship. First, these models are necessarily data intensive. The need for data on local capital stock, with some frequency of observation (annually in the current application), data on human capital, and data on production output are examples of data requirements that make these types of models inappropriate for some settings. We will revisit this matter shortly. Second, the relationship between the basic production function and some identifying relationship must be structured. An example is Cadot, Rollet and Stephan (2006) who model transportation and political effort for 'pork barrel' spending in a simultaneous equations approach. These authors structure an equation that measures political lobbying intensity to in effect identify the endogenous variable in the production function. This approach is attractive in settings where the identifying relationship can be plausibly structured. Finally, adding additional structure to the model imposes the potential for additional endogeneity problems beyond those existing with the transportation infrastructure.

The first two of these limitations present a particular nuisance to the issue we address. Our research explores the effects of bus transit systems in small cities over a period of less than two decades. While we have data on annual capital expenditures on transit, data on the capital stock for a regional production function is nearly non-existent. Further, use of human capital 
estimates over the 1992-2006 period would necessitate the interpolation of no more than two census periods onto local population estimates. For these reasons we have chosen to use a simpler empirical method and the standard treatment for addressing the potential for endogeneity bias.

A pure treatment model offers an alternative to a structured production function. This approach has been used in a number of settings to model potentially endogenous firm entrance into regions (see Basker 2006; Hicks 2008). This is a far more appropriate choice for our research question. First, we believe that the question we seek to answer offers a fairly controlled examination of the data, which would serve to minimize endogeneity bias. We have limited our sample to 79 fairly homogenous communities in the Great Lakes region. This provides a quasiexperimental element to the empirical approach, though it is not a formal quasi-experimental technique. The choice of these locations was made specifically to establish a heterogeneous sample. Second, the questions we are asking appear to have less endogeneity concern than other related questions in the literature. For example, the papers noted above focus on either aggregate infrastructure expenditures in a region (which clearly suffer danger of endogeneity), and location decisions by retail firms (another obvious candidate for locating due to regional growth). In contrast our list of growth and social service measures do not, on their face, present a robust concern regarding endogeneity of a bus transit system. Indeed, none of these variables would appear to present the bias inducing risk of a measure of public capital stock for example. Since the largest component of funding for these bus systems is primarily federal, it is in our judgment a fairly benign endogeneity concern here. While there are formal mechanisms for testing for endogeneity, the introduction of a production function or simultaneous equation model in this setting offers some significant drawbacks beyond the data limitations. Were we to have data on 
public and private capital stock, we would need a convincing identification strategy for the presence of a city bus system. We view this as a fairly elusive task. As a consequence we will test for, rather than attempt to pre-emptively correct for, the presence of endogeneity.

Our approach is to employ a pure treatment model to examine the effects of transit on economic development outcomes. In the model we control for the presence of a transit system and fixed effects which take into account differences in the counties that do not vary over time. The model takes the following form:

$$
Y_{i t}=\propto+\beta_{i t}(\text { Bus })+\varphi t+\theta \delta_{t-1}+\gamma_{i}+\varepsilon_{i t}
$$

where $\mathrm{Y}_{\mathrm{it}}$ represents the various economic development measures considered in this analysis: growth in real per capita personal income, employment growth, population growth, the unemployment rate, the poverty rate, growth in real family assistance, and growth in food stamps. Our basic model specifies economic development as a function of an intercept, a binary variable for counties that have bus systems, a time trend, autoregressive terms, fixed effects dummies, and a white noise error term. We also specify a second model in which we use operating costs per capita for the county’s bus system as a measure of the size of the bus system in place of the binary bus variable. We expect that larger bus systems will have a greater effect on employment and transfer payments.

Finally, only six counties opened bus systems over the 1992 to 2006 period. These six counties identify the model. We estimate a separate set of models that include only these six counties with bus systems and the various control groups.

The models are estimated using generalized least squares. We correct for heteroscedasticity using White's (1980) method. We include autoregressive terms to account for 
autocorrelation observed in the basic model. We also conduct Hausman's endogeneity test to test for endogeneity bias in each regression where transit is statistically significant. In each case we were able to exclude the presence of endogeneity between transit and the dependent variable for each model.

\section{RESULTS}

The results of the regression analysis are shown in Tables 3 and 4 . Table 3 includes all counties with bus systems and each control group. Table 4 includes counties which started bus systems and each control group.

The presence of a bus transit system is negatively related to growth in food stamp payment per capita. Average growth in food stamp payments was $\$ 1.50$ to $\$ 2.00$ lower per capita in counties with bus transit. The presence of bus transit is also positively related to population growth and employment growth in counties starting bus systems over this study period. Average employment growth was higher by about 400 workers in these counties.

The size of the bus system (measured by operating expenditures per capita) in a county affects the low-income population. Annual real growth in family assistance per capita is lower (by an average of $\$ 0.18$ to $\$ 0.61$ per dollar of operating expenses) in counties with transit systems. Annual real growth in food stamp payments is lower (by an average of $\$ 0.60$ to $\$ 0.70$ cents per dollar of operating expenses) in counties with starting transit systems over the study period. The population captured by these socioeconomic variables is low-income, single mothers. Previous research suggests that a large percentage of this demographic does not have access to a reliable automobile for personal transportation and that alternatives are necessary to meet their transportation needs. While previous studies focusing on larger cities (Sanchez, Shen, Peng 2004; Bania, Leete, Coulton 2008) showed that access to public transportation had no 
impact on labor market outcomes for low income population in large cities (Atlanta, Baltimore, Dallas, Denver, Milwaukee, Portland, Cleveland), the findings discussed above indicate that public transportation may have a positive impact on job access in small cities.

The presence of bus transit and the size of the bus system also affects the unemployed population. The unemployment rate is significantly lower (by 0.2 to 0.3 percentage point) in counties with transit systems. This suggests that counties with transit may experience lower levels of unemployment and /or shorter unemployment spells.

These findings suggest that transit systems increase the access of low income individuals to jobs. However, despite increased access to jobs, earnings are not high enough to positively affect earnings growth and the associated poverty rate. There are a variety of effects at work here. Transit increases access to jobs which increases labor supply. In particular, the low skill, low wage segment of the labor market is affected. More workers willing and able to supply labor in this submarket put downward pressure on wages which dampens earnings growth.

Another mechanism that explains the negative relationship between increased access to jobs and income growth is related to the distance between residential and work locations. Increased distance between the residential and work location may lead to longer travel times and more complex and unreliable transit trips or lower access to information about job opportunities (Bania, Leete and Coulton 2008, 2181). Problems with the reliability of transit and/or higher commuting costs may affect the employment level, duration of employment spells increased absenteeism, or tardiness for workers commuting via transit. These issues will in turn affect earnings and/or hours worked due to lower job performance because of poor job matches or slower accumulation of experience which may ultimately lead to stagnation in aggregate earnings growth as measured by per capita income growth and the poverty rate. 
The findings that the presence of bus transit in small cities has a positive impact on labor market variables in small cities (in contrast to the limited economic development impact of rail transit in larger cities) may result from the flexibility of bus transit relative to rail. Unlike fixed route rail, bus transit routes can be adjusted to serve new or growing retail centers or industrial parks, for example. In addition, the negative labor market effects associated with spatial mismatch are likely to be less pronounced in smaller cities relative to larger cities.

\section{SUMMARY AND EXTENSIONS}

Previous analysis suggests a limited but positive relationship between public transportation, particularly rail systems, and economic growth. The focus of the current analysis is to examine the impact of bus transit on traditional and nontraditional measures of economic development using a sample of counties with small cities in the upper Midwest. Relative to counties without bus systems, counties with bus systems have significantly lower unemployment rates, lower growth in family assistance and food stamp payments, and higher population and employment growth. In addition, the size of the bus system (as measured by operating costs per capita) matters. As the size (reach) of the bus system increases, family assistance and food stamp payments decrease. The statistical results provide limited evidence that the poverty rate is higher in counties with bus systems. We find that transit has no effect on per capita income growth and limited evidence that counties with bus systems have lower growth in aggregate income. The positive impact on job access which reduces payments for family assistance and food stamps is tempered by higher poverty rates (in one model) and a potentially negative effect on income. These results are likely driven by supply side effects in the labor market.

Nevertheless, this analysis suggests that there are previously unquantified effects associated with investment in bus transit in small cities. Transit has a positive effect on getting 
people to work suggesting the transit has positive effects on the distribution of employment. However this increased capacity to work does not result in statistically discernable income growth and potentially has a negative effect on the distribution of income (as measured by the poverty rate). This research offers only tentative direction to understanding this effect. One hypothesis that deserves comment is the proposition that the growth in low wage workers (as a consequence of the increased transit availability) has dampened overall income growth in regions. This hypothesis is ripe for further research.

Future research should examine this issue more closely to better understanding the effect of bus transit access on individual workers. Previous studies examining the relationship between job access and transit have used micro data on individual workers or potential workers in a variety of large cities. This work should be extended to employment outcomes and transportation usage for workers in smaller cities that have and do not have transit systems. 
Appendix 1: Transit Systems included in the analysis

\begin{tabular}{|c|c|c|c|}
\hline Transit System Name & City & County & State \\
\hline Bloomington-Normal Public Transit System & Bloomington & McLean & IL \\
\hline City of Danville/Danville Mass Transit & Danville & Vermilion & $\mathrm{IL}$ \\
\hline Decatur Public Transit System & Decatur & Macon & IL \\
\hline City of Kankakee Taxi Van Program & Kankakee & Kankakee & IL \\
\hline River Valley Metro Mass Transit District & Kankakee & Kankakee & $\mathrm{IL}$ \\
\hline Greater Peoria Mass Transit District & Peoria & Peoria & IL \\
\hline Champaign-Urbana Mass Transit District & Urbana & Champaign & IL \\
\hline City of Anderson Transportation System & Anderson & Madison & IN \\
\hline Bloomington Public Transportation Corporation & Bloomington & Monroe & IN \\
\hline $\begin{array}{l}\text { Greater Lafayette Public Transportation } \\
\text { Corporation }\end{array}$ & Lafayette & Tippecanoe & IN \\
\hline Muncie Indiana Transit System & Muncie & Delaware & IN \\
\hline Goshen Transit System & South Bend & Elkhart & IN \\
\hline Heart City Rider Program & South Bend & Elkhart & IN \\
\hline Michiana Area Council of Governments & South Bend & Elkhart & IN \\
\hline Terre Haute Transit Utility & Terre Haute & Vigo & IN \\
\hline Battle Creek Transit & Battle Creek & Calhoun & MI \\
\hline Bay Metropolitan Transit Authority & Bay City & Bay & MI \\
\hline Twin Cities Area Transportation Authority & Benton Harbor & Berrien & MI \\
\hline City of Jackson Transportation Authority & Jackson & Jackson & MI \\
\hline Muskegon Area Transit System & Muskegon Heights & Muskegon & MI \\
\hline Niles Dial-A-Ride & Niles & Berrien & MI \\
\hline Blue Water Area Transportation Commission & Port Huron & St. Clair & MI \\
\hline Portage Area Regional Transportation Authority & Kent & Portage & $\mathrm{OH}$ \\
\hline Campus Bus Service & Kent & Portage & $\mathrm{OH}$ \\
\hline Allen County Regional Transit Authority & Lima & Allen & $\mathrm{OH}$ \\
\hline Richland County Transit & Mansfield & Richland & $\mathrm{OH}$ \\
\hline City of Newark Transit Operations & Newark & Licking & $\mathrm{OH}$ \\
\hline Licking County Transit Board & Newark & Licking & $\mathrm{OH}$ \\
\hline Springfield City Area Transit & Springfield & Clark & $\mathrm{OH}$ \\
\hline Steel Valley Regional Transit Authority & Steubenville & Jefferson & $\mathrm{OH}$ \\
\hline County of Lebanon Transit Authority & Lebanon & Lebanon & PA \\
\hline Centre Area Transportation Authority & State College & Centre & PA \\
\hline Williamsport Bureau of Transportation & Williamsport & Lycoming & PA \\
\hline City of Appleton - Valley Transit & Appleton & Outagamie & WI \\
\hline City of Beloit Transit System & Beloit & Rock & WI \\
\hline Eau Claire Transit & Eau Claire & Eau Claire & WI \\
\hline Fond du Lac Area Transit & Fond du Lac & Fond du Lac & WI \\
\hline Green Bay Metro & Green Bay & Brown & WI \\
\hline
\end{tabular}




\begin{tabular}{|l|l|l|l|}
\hline Janesville Transit System & Janesville & Rock & WI \\
\hline Kenosha Transit & Kenosha & Kenosha & WI \\
\hline LaCrosse Municipal Transit Utility & LaCrosse & La Crosse & WI \\
\hline Oshkosh Transit System & Oshkosh & Winnebago & WI \\
\hline Belle Urban System - Racine & Racine & Racine & WI \\
\hline Sheboygan Transit System & Sheboygan & Sheboygan & WI \\
\hline Waukesha County Transit System & Waukesha & Waukesha & WI \\
\hline City of Waukesha Transit Commission & Waukesha & Waukesha & WI \\
\hline Wausau Area Transit System & Wausau & Marathon & WI \\
\hline
\end{tabular}




\section{REFERENCES}

Allard, Scott W. and Danzinger, Sheldon. 2003. Proximity and opportunity: How residence and race affect the employment of welfare recipients. Housing Policy Debate 13(4): 675-700.

Bania, Neil, Leete, Laura, Coulton, Claudia. 2003. Job access, employment and earnings: Outcomes for welfare leavers in U.S. urban labour market. Urban Studies 45(11): 21792202.

Basker, Emek. "Job creation or destruction? 2005. Labor market effects of Wal-Mart expansion. Review of Economics and Statistics, 87(1): 174-83.

Baum, Charles L. 2009. The effects of vehicle ownership on employment. Journal of Urban Economics 66: 151-163.

Bollinger, Christopher R. and Ihlanfeldt, Keith R. 2003. The intraurban spatial distribution of employment" which government interventions make a difference? Journal of Urban Economics 53: 396-412.

---. 1997. "The impact of rapid rail transit on economic development: The case of Atlanta's MARTA. Journal of Urban Economics 42: 179-204.

Bowes, David R. and Ihlanfeldt, Keith R. 2001. Identifying the impacts of rail transit stations on residential property values. Journal of Urban Economics 50: 1-25.

Cadot, Olivier; Röller, Lars-Hendrik; Stephan, Andreas. 2006. Contribution to productivity or pork barrel? The two faces of infrastructure investment. Journal of Public Economics, . 90.6/7: 1133-1153.

Cervero, Robert and Landis, John. 1997. Twenty ears of the Bay Area Rapid Transit System: Land use and development impacts. Transportation Research Part A: Policy and Practice 31.4: 309-333.

Dalenburg, Douglas R. Partridge, Mark D. and Rickman, Dan S. 1998. Public infrastructure: Pork or jobs creator? Public Finance Review 26.1: 24-52.

Eberts, Randall W. 1991. Some empirical evidence on the linkage between public infrastructure and local economic development. In H.W. Herzog Jr. and A.M. Schlottmann, eds., Industry Location and Public Policy. Knoxville, TN: University of Tennessee Press.

Fox, William F. and Murray, Matthew N. 1990. Local public policies and interregional business development. Southern Economic Journal, 57.2: 413-27.

Gramlich, Edward M. 1994. Infrastructure investment: A review essay. Journal of Economic Literature 32: 1176-1196. 
Green, Rodney D. and James, David M. 1993. Rail Transit Station Area Development Small Area Modeling in Washington, D.C. Armonk, NY: M.E. Sharpe.

Gurley, Tami and Bruce, Donald. 2005. The effects of car access on employment outcomes for welfare recipients. Journal of Urban Economics 58: 250-272.

Hicks, Michael J. 2008. Estimating Wal-Mart's impacts in Maryland: A test of identification strategies and endogeneity tests. Eastern Economic Journal, 33.3: 56-73.

Hicks, Michael J. 2006. Transportation infrastructure, retail clustering and local public finance: Evidence from Wal-Mart's expansion. Regional Economic Development 2.2: 100-114.

Hicks, Michael J. 2003. A quasi-experimental analysis of the impact of casino gambling on regional economic performance. Proceedings of the National Tax Association, 181-188.

Holtz-Eakin, Douglas. 1994. Public sector capital and the productivity puzzle. Review of Economics and Statistics.76.1: 12-21.

Ihlanfeldt, Keith R. and Sjoquist, David L. 1990. Job accessibility and racial differences in youth employment rates. American Economic Review 80.1: 267-277.

Kain, John F. 1968. Housing segregation, Negro employment and metropolitan decentralization. Quarterly Journal of Economics 82: 175-97.

Ong, Paul M. 2002. Car ownership and welfare-to-work. Journal of Policy Analysis and Management 21.2: 239-252.

--- and Blumenberg, Evelyn. 1998. “Job access, commute and travel burden among welfare recipients.” Urban Studies 35.1: 77-93.

Patridge, Mark D. and Rickman, Dan S. 2008. Does a rising tide lift all metropolitan boats? Assessing poverty dynamics by metropolitan size and county type. Growth and Change 39.2: 283-312.

Raphael, Steven and Rice , Lorien. 2002. Car ownership, employment, and earnings. Journal of Urban Economics 52: 109-130.

Reed, W. Robert and Cynthia L. Rogers 2003. A study of quasi-experimental control group methods for estimating policy impacts. Regional Science and Urban Economics 33.1: 325.

Rodriguez, Daniel A. and Targa, Filipe. "Value of Accessibility to Bogota’s Bus Rapid Transit.” Transport Reviews 24.5 (2004) 587-610.

Sanchez, Thomas W. “Poverty, policy and public transportation.” Transportation Research Part A 42 (2008) 833-841. 
---. 1999. The connection between public transit and employment: The cases of Portland and Atlanta. Journal of the American Planning Association 65.3: 284-296.

---, Shen, Qing and Peng, Zhong-Ren. 2004. Transit motility, jobs access and low-income labour participation in US metropolitan areas. Urban Studies 41.7: 1313-1331.

Wasylenko, Michael. 1997. Taxation and economic development: The state of the economic literature. New England Economic Review March/April: 37-52.

White, Halbert. 1980. A heteroskedasticity-consistent covariance matrix estimator and a direct test for heteroskedasticity. Econometrica, 48.4: 817-38. 


\section{Author Biographies}

Dagney Faulk, PhD, Director of Research

Center for Business and Economic Research, Ball State University

Dr. Faulk's research interests include state and local public finance and economic development issues. Her research has appeared in the National Tax Journal, the Review of Regional Studies and State Tax Notes. Prior to joining the Center for Business and Economic Research (CBER), she was Associate Professor of Economics at Indiana University Southeast. She has also worked at the World Bank, the U.S. Department of Housing and Urban Development, and the Indiana Legislative Services Agency. She received her doctorate in economics from the Andrew Young School of Policy Studies at Georgia State University. She has worked on a variety of research studies focusing on Indiana fiscal issues.

Michael J. Hicks, PhD, Director and Associate Professor of Economics Center for Business and Economic Research, Ball State University Nationally known for his research on energy markets and the economic impact of Wal-Mart, Michael Hicks has authored two books and more than 60 scholarly works focusing on state and local public policy, including an emphasis on tax and expenditure policy, environmental regulation, alternative and traditional energy, and the economic impact of Wal-Mart on local economies. Prior to joining Ball State's Center for Business and Economic Research (CBER), Dr. Hicks was associate professor of economics at the Air Force Institute of Technology's Graduate School of Engineering and Management at Wright-Patterson Air Force Base in Dayton, Ohio. He also serves as adjunct scholar for the Mackinac Center for Public Policy. Hicks earned doctoral and master's degrees in economics from the University of Tennessee and a bachelor's degree in economics from Virginia Military Institute. 
Tables

Table 1 -- Variable Description and Sources

\begin{tabular}{|c|c|c|}
\hline Variable & Definition & Source \\
\hline Bus Dummy & $\begin{array}{l}=1 \text { if there is a bus system in } \\
\text { the county } \\
=0 \text { otherwise }\end{array}$ & National Transit Database \\
\hline $\begin{array}{l}\text { Started Bus System } \\
\text { Dummy }\end{array}$ & $\begin{array}{l}=1 \text { if a bus system was started } \\
\text { in the county between } 1992 \\
\text { and } 2006 \\
=0 \text { otherwise }\end{array}$ & National Transit Database \\
\hline $\begin{array}{l}\text { Real operating expenditures } \\
\text { per capita }(\$)\end{array}$ & $\begin{array}{l}\text { Annual operating expenses } \\
\text { divided by the county } \\
\text { population. }\end{array}$ & $\begin{array}{l}\text { National Transit Database and } \\
\text { REIS }\end{array}$ \\
\hline $\begin{array}{l}\text { Real Growth in Family } \\
\text { Assistance per capita (\$) }\end{array}$ & $\begin{array}{l}\text { Annual growth in per capita } \\
\text { state-administered benefit } \\
\text { payments to low-income } \\
\text { families (AFDC or TANF) }\end{array}$ & $\begin{array}{l}\text { Regional Economic } \\
\text { Information System (REIS) }\end{array}$ \\
\hline $\begin{array}{l}\text { Real Growth in Food Stamps } \\
\text { per capita(\$) }\end{array}$ & $\begin{array}{l}\text { Annual growth in per capita } \\
\text { food stamps issued to low- } \\
\text { income individuals }\end{array}$ & Transit Dummy \\
\hline $\begin{array}{l}\text { Real Per Capital Income } \\
\text { Growth (\$) }\end{array}$ & $\begin{array}{l}\text { Annual change in per capita } \\
\text { income }\end{array}$ & $\begin{array}{l}\text { Regional Economic } \\
\text { Information System (REIS) }\end{array}$ \\
\hline Population Growth & Annual change in population & $\begin{array}{l}\text { Regional Economic } \\
\text { Information System (REIS) }\end{array}$ \\
\hline Employment Growth & Annual change in employment & Bureau of Labor Statistics \\
\hline Unemployment Rate & $\begin{array}{l}\text { The percentage of the labor } \\
\text { force that is not employed }\end{array}$ & Bureau of Labor Statistics \\
\hline Poverty Rate & $\begin{array}{l}\text { The percentage of people with } \\
\text { incomes below the poverty } \\
\text { threshold }\end{array}$ & $\begin{array}{l}\text { Small Area Income and } \\
\text { Poverty Statistics, U.S. Census } \\
\text { Bureau }\end{array}$ \\
\hline
\end{tabular}


Table 2 - Descriptive Statistics

\begin{tabular}{|c|c|c|c|c|c|c|c|c|c|c|c|c|c|c|c|}
\hline & \multicolumn{3}{|c|}{$\begin{array}{c}\text { Propensity Scoring } \\
\text { Counties without bus } \\
\text { systems } \\
\end{array}$} & \multicolumn{3}{|c|}{$\begin{array}{c}\text { NEG Method } \\
\text { Counties without bus } \\
\text { systems }\end{array}$} & \multicolumn{3}{|c|}{$\begin{array}{c}\text { Like city (1950 Population) } \\
\text { Counties without bus } \\
\text { systems }\end{array}$} & \multicolumn{3}{|c|}{$\begin{array}{l}\text { Counties with bus } \\
\text { systems* }\end{array}$} & \multicolumn{3}{|c|}{$\begin{array}{c}\text { Counties starting bus } \\
\text { systems }\end{array}$} \\
\hline & Mean & $\begin{array}{r}\text { Std. } \\
\text { Dev. }\end{array}$ & Obs. & Mean & $\begin{array}{r}\text { Std. } \\
\text { Dev. }\end{array}$ & Obs. & Mean & $\begin{array}{r}\text { Std. } \\
\text { Dev. }\end{array}$ & Obs. & Mean & $\begin{array}{r}\text { Std. } \\
\text { Dev. }\end{array}$ & Obs. & Mean & $\begin{array}{r}\text { Std. } \\
\text { Dev. }\end{array}$ & Obs. \\
\hline $\begin{array}{l}\text { Bus Dummy } \\
\text { Started Bus System }\end{array}$ & 0 & 0 & 585 & 0 & 0 & 585 & 0 & 0 & 600 & 0.92 & 0.27 & 585 & 0.47 & 0.50 & 90 \\
\hline $\begin{array}{l}\text { Dummy } \\
\text { Real Operating Expenses } \\
\text { per Capita for Bus } \\
\text { System (\$) }\end{array}$ & 0 & 0 & 585 & 0 & 0 & 585 & 0 & 0 & 600 & 9.47 & 7.93 & 585 & 1.30 & 0.00 & 90 \\
\hline $\begin{array}{l}\text { Growth in Real Family } \\
\text { Assistance per Capita (\$) } \\
\text { Growth in Real Food } \\
\text { Stamp Payments per } \\
\text { Capita (\$) }\end{array}$ & -1.76 & 5.22 & 546 & -0.05 & 4.75 & 546 & -0.35 & 5.71 & 560 & -2.24 & 4.78 & 546 & -1.84 & 4.95 & 84 \\
\hline $\begin{array}{l}\text { Growth in Real Personal } \\
\text { Income }(\$ 000)\end{array}$ & 6,338 & 20,943 & 546 & 8,816 & 27,256 & 546 & 18,394 & 36,258 & 560 & 36,040 & 64,535 & 546 & 39,880 & 45,607 & 84 \\
\hline $\begin{array}{l}\text { Growth in Real Per } \\
\text { Capita Income }(\$)\end{array}$ & 116 & 335 & 546 & 107 & 367 & 547 & 129 & 283 & 560 & 159 & 307 & 546 & 157 & 285 & 84 \\
\hline Population Growth & 29 & 349 & 546 & 185 & 783 & 546 & 351 & 985 & 560 & 752 & 1,223 & 546 & 1,272 & 1,104 & 84 \\
\hline Employment Growth & 183 & 633 & 546 & 285 & 981 & 546 & 426 & 1,293 & 560 & 560 & 1,690 & 546 & 778 & 1,638 & 84 \\
\hline Unemployment Rate (\%) & 5.83 & 1.89 & 585 & 5.47 & 1.60 & 585 & 5.89 & 1.79 & 600 & 5.02 & 1.72 & 585 & 4.95 & 1.66 & 90 \\
\hline Poverty Rate (\%) & 10.44 & 2.42 & 429 & 10.44 & 2.42 & 429 & 10.91 & 3.32 & 440 & 10.56 & 3.08 & 429 & 9.01 & 1.89 & 66 \\
\hline
\end{tabular}

*Includes counties starting bus systems. 
Table 3 -- All Counties [p-value]

\begin{tabular}{|c|c|c|c|c|c|c|}
\hline \multirow[b]{2}{*}{ Variables } & \multicolumn{2}{|c|}{ PROPENSITY SCORING METHOD } & \multicolumn{2}{|c|}{ NEG METHOD } & \multicolumn{2}{|c|}{ LIKE CITY } \\
\hline & Transit Dummy & $\begin{array}{c}\text { Real Operating } \\
\text { Expenses per capita }\end{array}$ & $\begin{array}{c}\text { Transit } \\
\text { Dummy }\end{array}$ & $\begin{array}{c}\text { Real Operating } \\
\text { Expenses per capita }\end{array}$ & $\begin{array}{c}\text { Transit } \\
\text { Dummy }\end{array}$ & $\begin{array}{c}\text { Real Operating } \\
\text { Expenses per capita }\end{array}$ \\
\hline $\begin{array}{l}\text { Real Growth in Family } \\
\text { Assistance per Capita }\end{array}$ & $\begin{array}{l}-0.422 \\
{[0.748]}\end{array}$ & $\begin{array}{l}-0.187^{*} \\
{[0.058]}\end{array}$ & $\begin{array}{l}-0.203 \\
{[0.872]}\end{array}$ & $\begin{array}{c}-0.154 \\
{[0.096]}\end{array}$ & $\begin{array}{l}-0.035 \\
{[0.973]}\end{array}$ & $\begin{array}{c}-0.245^{* * *} \\
{[0.009]}\end{array}$ \\
\hline $\begin{array}{l}\text { Adj. R-sq.; F-stat } \\
\text { D-W stat; Obs. }\end{array}$ & $\begin{array}{l}0.15 ; 2.97 \\
2.02 ; 929 \\
\end{array}$ & $\begin{array}{l}0.15 ; 3.02 \\
2.02 ; 929\end{array}$ & $\begin{array}{l}0.17 ; 3.39 \\
1.99 ; 927\end{array}$ & $\begin{array}{l}0.17 ; 3.43 \\
1.99 ; 927\end{array}$ & $\begin{array}{l}0.15 ; 3.1 \\
2.03 ; 948\end{array}$ & $\begin{array}{l}0.16 ; 3.18 \\
2.03 ; 948\end{array}$ \\
\hline $\begin{array}{l}\text { Real Growth in Food Stamp } \\
\text { Payments per Capita }\end{array}$ & $\begin{array}{c}-1.994 * * * \\
{[0.003]}\end{array}$ & $\begin{array}{c}-0.083 \\
{[0.155]}\end{array}$ & $\begin{array}{c}-1.76^{* * * *} \\
{[0.008]} \\
\end{array}$ & $\begin{array}{c}-0.044 \\
{[0.423]} \\
\end{array}$ & $\begin{array}{l}-1.515^{*} \\
{[0.067]} \\
\end{array}$ & $\begin{array}{c}-0.106^{* *} \\
{[0.027]}\end{array}$ \\
\hline $\begin{array}{l}\text { Adj. R-sq.; F-stat } \\
\text { D-W stat; Obs. }\end{array}$ & $\begin{array}{c}0.65 ; 23.09 \\
1.98 ; 936 \\
\end{array}$ & $\begin{array}{c}0.65 ; 22.92 \\
1.98 ; 936 \\
\end{array}$ & $\begin{array}{l}0.67 ; 24.7 \\
1.95 ; 936 \\
\end{array}$ & $\begin{array}{c}0.67 ; 24.48 \\
1.95 ; 936 \\
\end{array}$ & $\begin{array}{l}0.60 ; 20.1 \\
2.03 ; 1027 \\
\end{array}$ & $\begin{array}{l}0.60 ; 20.1 \\
2.03 ; 1027 \\
\end{array}$ \\
\hline $\begin{array}{l}\text { Real Growth in Personal Income } \\
(000)\end{array}$ & $\begin{array}{c}-9,069 \\
{[0.196]}\end{array}$ & $\begin{array}{l}-1,195^{*} \\
{[0.064]}\end{array}$ & $\begin{array}{c}-7,447 \\
{[0.302]}\end{array}$ & $\begin{array}{c}-894 \\
{[0.176]}\end{array}$ & $\begin{array}{l}-9.126 \\
{[0.145]}\end{array}$ & $\begin{array}{c}-0.227 \\
{[0.736]}\end{array}$ \\
\hline $\begin{array}{l}\text { Adj. R-sq.; F-stat } \\
\text { D-W stat; Obs. }\end{array}$ & $\begin{array}{l}0.29 ; 5.76 \\
2.04 ; 936\end{array}$ & $\begin{array}{l}0.29 ; 5.77 \\
2.04 ; 936\end{array}$ & $\begin{array}{l}0.28 ; 5.57 \\
2.03 ; 936\end{array}$ & $\begin{array}{l}0.28 ; 5.56 \\
2.03 ; 936\end{array}$ & $\begin{array}{l}0.26 ; 5.18 \\
20.3 ; 948\end{array}$ & $\begin{array}{l}0.26 ; 5.14 \\
2.03 ; 948\end{array}$ \\
\hline $\begin{array}{l}\text { Real Growth in Per Capita } \\
\text { Income }\end{array}$ & $\begin{array}{l}-57.13 \\
{[0.342]}\end{array}$ & $\begin{array}{c}-3,518.4 \\
{[0.499]}\end{array}$ & $\begin{array}{l}-48,638 \\
{[0.431]} \\
\end{array}$ & $\begin{array}{c}-2,041.8 \\
{[0.700]}\end{array}$ & $\begin{array}{l}-99.798 \\
{[0.102]} \\
\end{array}$ & $\begin{array}{l}-1.081 \\
{[0.810]}\end{array}$ \\
\hline $\begin{array}{l}\text { Adj. R-sq.; F-stat } \\
\text { D-W stat; Obs. }\end{array}$ & $\begin{array}{l}0.07 ; 1.84 \\
2.05 ; 936 \\
\end{array}$ & $\begin{array}{c}0.067 ; 1.83 \\
2.05 ; 936 \\
\end{array}$ & $\begin{array}{l}0.07 ; 1.86 \\
20.3 ; 936 \\
\end{array}$ & $\begin{array}{l}0.07 ; 1.85 \\
2.03 ; 936 \\
\end{array}$ & $\begin{array}{c}0.048 ; 1.59 \\
20.2 ; 948 \\
\end{array}$ & $\begin{array}{l}0.069 ; 1.95 \\
2.04 ; 1027 \\
\end{array}$ \\
\hline Population Growth & $\begin{array}{l}150.28 \\
{[0.136]} \\
\end{array}$ & $\begin{array}{c}10.49 \\
{[0.307]} \\
\end{array}$ & $\begin{array}{c}138.7 \\
{[0.176]} \\
\end{array}$ & $\begin{array}{c}12.36 \\
{[0.266]} \\
\end{array}$ & $\begin{array}{c}177.103^{* *} \\
{[0.0496]} \\
\end{array}$ & $\begin{array}{c}14.926 \\
{[0.177]} \\
\end{array}$ \\
\hline $\begin{array}{l}\text { Adj. R-sq.; F-stat } \\
\text { D-W stat; Obs. }\end{array}$ & $\begin{array}{l}0.84 ; 65.5 \\
2.04 ; 1014 \\
\end{array}$ & $\begin{array}{l}0.83 ; 62.6 \\
2.03 ; 1014 \\
\end{array}$ & $\begin{array}{l}0.85 ; 66.2 \\
1.94 ; 936 \\
\end{array}$ & $\begin{array}{c}0.84 ; 59.96 \\
1.93 ; 936 \\
\end{array}$ & $\begin{array}{c}0.867 ; 76.59 \\
1.95 ; 948 \\
\end{array}$ & $\begin{array}{c}0.855 ; 75.84 \\
1.99 ; 1027 \\
\end{array}$ \\
\hline Employment Growth & $\begin{array}{c}356.52 \\
{[0.122]} \\
\end{array}$ & $\begin{array}{c}42.162 \\
{[0.104]} \\
\end{array}$ & $\begin{array}{c}378.24 \\
{[0.104]} \\
\end{array}$ & $\begin{array}{c}44.509 * \\
{[0.088]} \\
\end{array}$ & $\begin{array}{c}307.041 \\
{[0.101]} \\
\end{array}$ & $\begin{array}{c}43.355^{*} \\
{[0.075]} \\
\end{array}$ \\
\hline $\begin{array}{l}\text { Adj. R-sq.; F-stat } \\
\text { D-W stat; Obs. }\end{array}$ & $\begin{array}{c}0.179 ; 3.52 \\
2.14 ; 936 \\
\end{array}$ & $\begin{array}{c}1.179 ; 3.52 \\
2.14 ; 936 \\
\end{array}$ & $\begin{array}{l}0.20 ; 3.89 \\
2.12 ; 936 \\
\end{array}$ & $\begin{array}{c}0.205 ; 3.98 \\
2.11 ; 936 \\
\end{array}$ & $\begin{array}{l}0.12 ; 2.62 \\
2.10 ; 948 \\
\end{array}$ & $\begin{array}{l}0.15 ; 3.33 \\
2.04 ; 1027 \\
\end{array}$ \\
\hline Unemployment Rate & $\begin{array}{c}-0.31 * * * \\
{[0.005]} \\
\end{array}$ & $\begin{array}{c}-0.01 \\
{[0.330]} \\
\end{array}$ & $\begin{array}{c}-0.304 * * * \\
{[0.005]} \\
\end{array}$ & $\begin{array}{c}-0.010 \\
{[0.342]} \\
\end{array}$ & $\begin{array}{c}-0.246 * * \\
{[0.018]} \\
\end{array}$ & $\begin{array}{c}-0.007 \\
{[0.529]} \\
\end{array}$ \\
\hline $\begin{array}{l}\text { Adj. R-sq.; F-stat } \\
\text { D-W stat; Obs. }\end{array}$ & $\begin{array}{c}0.872 ; 86.56 \\
2.05 ; 1014 \\
\end{array}$ & $\begin{array}{l}0.87 ; 86.19 \\
2.05 ; 1014 \\
\end{array}$ & $\begin{array}{l}0.867 ; 82.8 \\
2.04 ; 1014 \\
\end{array}$ & $\begin{array}{l}0.867 ; 82.6 \\
2.05 ; 1014 \\
\end{array}$ & $\begin{array}{c}0.89 ; 104.87 \\
2.03 ; 1027 \\
\end{array}$ & $\begin{array}{c}0.892 ; 104.33 \\
2.03 ; 1027 \\
\end{array}$ \\
\hline $\begin{array}{l}\text { Poverty Rate } \\
\text { Yr = 1993, 1995, 1997-2005 }\end{array}$ & $\begin{array}{c}-0.17 \\
{[0.617]}\end{array}$ & $\begin{array}{l}-0.0079 \\
{[0.825]}\end{array}$ & $\begin{array}{c}-0.170 \\
{[0.617]}\end{array}$ & $\begin{array}{l}-0.0079 \\
{[0.825]}\end{array}$ & $\begin{array}{c}0.087 \\
{[0.682]}\end{array}$ & $\begin{array}{c}0.133^{* * *} \\
{[0.000]}\end{array}$ \\
\hline $\begin{array}{l}\text { Adj. R-sq.; F-stat } \\
\text { D-W stat; Obs. }\end{array}$ & $\begin{array}{c}0.94 ; 112.5 \\
1.84 ; 546\end{array}$ & $\begin{array}{c}0.94 ; 112.6 \\
1.84 ; 546 \\
\end{array}$ & $\begin{array}{c}0.943 ; 112.5 \\
1.84 ; 546 \\
\end{array}$ & $\begin{array}{c}0.943 ; 112.6 \\
1.84 ; 546 \\
\end{array}$ & $\begin{array}{c}0.949 ; 182.2 \\
1.09 ; 790 \\
\end{array}$ & $\begin{array}{c}0.947 ; 172.95 \\
1.10 ; 790 \\
\end{array}$ \\
\hline
\end{tabular}

Significance: ${ }^{*} 0.1$ level, ${ }^{* *} 0.05$ level; $* * * 0.01$ level 
Table 4: Six Counties that added bus systems and counties without bus systems [p-value]

\begin{tabular}{|c|c|c|c|c|c|c|}
\hline \multirow[b]{2}{*}{ Variables } & \multicolumn{2}{|c|}{ PROPENSITY SCORING METHOD } & \multicolumn{2}{|c|}{ NEG METHOD } & \multicolumn{2}{|c|}{ LIKE CITY } \\
\hline & $\begin{array}{l}\text { Transit } \\
\text { Dummy }\end{array}$ & $\begin{array}{c}\text { Real Operating } \\
\text { Expenses per capita }\end{array}$ & $\begin{array}{l}\text { Transit } \\
\text { Dummy }\end{array}$ & $\begin{array}{c}\text { Real Operating } \\
\text { Expenses per capita }\end{array}$ & $\begin{array}{l}\text { Transit } \\
\text { Dummy }\end{array}$ & $\begin{array}{c}\text { Real Operating } \\
\text { Expenses per capita }\end{array}$ \\
\hline $\begin{array}{l}\text { Real Growth in Family } \\
\text { Assistance per Capita }\end{array}$ & $\begin{array}{c}-0.22 \\
{[0.866]}\end{array}$ & $\begin{array}{c}-0.461^{* * *} \\
{[0.0097]}\end{array}$ & $\begin{array}{c}-0.054 \\
{[0.974]}\end{array}$ & $\begin{array}{c}-0.611^{* * *} \\
{[0.000]}\end{array}$ & $\begin{array}{c}-0.526 \\
{[0.658]}\end{array}$ & $\begin{array}{c}-0.529 \\
{[0.004]}\end{array}$ \\
\hline $\begin{array}{l}\text { Adj. R-sq.; F-stat } \\
\text { D-W stat; Obs. }\end{array}$ & $\begin{array}{l}0.15 ; 3.02 \\
2.00 ; 533\end{array}$ & $\begin{array}{l}0.23 ; 3.09 \\
2.01 ; 533\end{array}$ & $\begin{array}{l}0.09 ; 2.16 \\
1.98 ; 531\end{array}$ & $\begin{array}{c}0.64 ; 21.36 \\
1.93 ; 540\end{array}$ & $\begin{array}{l}0.18 ; 3.48 \\
2.03 ; 548\end{array}$ & $\begin{array}{c}0.185 ; 3.54 \\
2.04 ; 548\end{array}$ \\
\hline $\begin{array}{l}\text { Real Growth in Food Stamp } \\
\text { Payments per Capita }\end{array}$ & $\begin{array}{c}-2.189 * * * \\
{[0.003]}\end{array}$ & $\begin{array}{c}-0.66 * * * \\
{[0.000]}\end{array}$ & $\begin{array}{c}-1.809 * * * \\
{[0.010]}\end{array}$ & $\begin{array}{c}-0.611 * * * \\
{[0.000]}\end{array}$ & $\begin{array}{c}-2.490^{* * *} \\
{[0.003]}\end{array}$ & $\begin{array}{c}-0.699 * * * \\
{[0.000]}\end{array}$ \\
\hline $\begin{array}{l}\text { Adj. R-sq.; F-stat } \\
\text { D-W stat; Obs. }\end{array}$ & $\begin{array}{c}0.61 ; 18.58 \\
1.98 ; 540\end{array}$ & $\begin{array}{c}0.62 ; 19.32 \\
1.99 ; 540\end{array}$ & $\begin{array}{c}0.635 ; 20.5 \\
1.92 ; 540 \\
\end{array}$ & $\begin{array}{c}0.644 ; 21.36 \\
1.93 ; 540 \\
\end{array}$ & $\begin{array}{c}0.541 ; 14.18 \\
1.98 ; 548 \\
\end{array}$ & $\begin{array}{c}0.552 ; 14.7 \\
1.99 ; 548\end{array}$ \\
\hline $\begin{array}{l}\text { Real Growth in Personal Income } \\
(000)\end{array}$ & $\begin{array}{c}-12,035^{*} \\
{[0.054]}\end{array}$ & $\begin{array}{c}382 \\
{[0.753]}\end{array}$ & $\begin{array}{c}-10,265 \\
{[0.129]}\end{array}$ & $\begin{array}{c}916 \\
{[0.427]}\end{array}$ & $\begin{array}{c}-5.76 \\
{[0.426]}\end{array}$ & $\begin{array}{c}1.651 \\
{[0.117]}\end{array}$ \\
\hline $\begin{array}{l}\text { Adj. R-sq.; F-stat } \\
\text { D-W stat; Obs. }\end{array}$ & $\begin{array}{l}0.19 ; 3.76 \\
2.05 ; 540 \\
\end{array}$ & $\begin{array}{c}0.193 ; 3.68 \\
2.05 ; 540\end{array}$ & $\begin{array}{l}0.20 ; 3.86 \\
2.03 ; 540 \\
\end{array}$ & $\begin{array}{l}0.20 ; 3.83 \\
2.03 ; 540 \\
\end{array}$ & $\begin{array}{l}0.23 ; 4.33 \\
2.03 ; 548 \\
\end{array}$ & $\begin{array}{l}0.23 ; 4.36 \\
20.2 ; 548 \\
\end{array}$ \\
\hline $\begin{array}{l}\text { Real Growth in Per Capita } \\
\text { Income }\end{array}$ & $\begin{array}{l}-75.87 \\
{[0.181]}\end{array}$ & $\begin{array}{c}-0.029 \\
{[0.831]}\end{array}$ & $\begin{array}{c}-60,211.2 \\
{[0.309]}\end{array}$ & $\begin{array}{l}3,606.0 \\
{[0.772]}\end{array}$ & $\begin{array}{l}-75.128 \\
{[0.271]}\end{array}$ & $\begin{array}{c}3.064 \\
{[0.799]}\end{array}$ \\
\hline $\begin{array}{l}\text { Adj. R-sq.; F-stat } \\
\text { D-W stat; Obs. }\end{array}$ & $\begin{array}{l}0.07 ; 1.90 \\
2.07 ; 540 \\
\end{array}$ & $\begin{array}{l}0.15 ; 3.04 \\
2.08 ; 540 \\
\end{array}$ & $\begin{array}{l}0.06 ; 1.76 \\
2.03 ; 540 \\
\end{array}$ & $\begin{array}{l}0.06 ; 1.74 \\
2.03 ; 540 \\
\end{array}$ & $\begin{array}{c}0.114 ; 1.31 \\
2.01 ; 548 \\
\end{array}$ & $\begin{array}{l}0.02 ; 1.29 \\
2.00 ; 548 \\
\end{array}$ \\
\hline Population Growth & $\begin{array}{l}183.55^{*} \\
{[0.077]} \\
\end{array}$ & $\begin{array}{c}42.88 \\
{[0.057]} \\
\end{array}$ & $\begin{array}{c}139.92 \\
{[0.162]} \\
\end{array}$ & $\begin{array}{c}38.35^{*} \\
{[0.077]} \\
\end{array}$ & $\begin{array}{c}219.345^{* *} \\
{[0.028]} \\
\end{array}$ & $\begin{array}{c}50.05 * * \\
{[0.014]} \\
\end{array}$ \\
\hline $\begin{array}{l}\text { Adj. R-sq.; F-stat } \\
\text { D-W stat; Obs. }\end{array}$ & $\begin{array}{c}0.73 ; 32.02 \\
1.90 ; 540 \\
\end{array}$ & $\begin{array}{c}0.73 ; 32.23 \\
1.90 ; 540 \\
\end{array}$ & $\begin{array}{l}0.76 ; 36.1 \\
1.97 ; 540 \\
\end{array}$ & $\begin{array}{c}0.76 ; 36.37 \\
1.98 ; 540 \\
\end{array}$ & $\begin{array}{c}0.83 ; 55.25 \\
1.99 ; 548 \\
\end{array}$ & $\begin{array}{c}0.83 ; 55.57 \\
1.99 ; 548 \\
\end{array}$ \\
\hline Employment Growth & $\begin{array}{c}390.85 * \\
{[0.099]} \\
\end{array}$ & $\begin{array}{c}136.83 * * * \\
{[0.000]}\end{array}$ & $\begin{array}{c}438.77 * \\
{[0.071]} \\
\end{array}$ & $\begin{array}{c}140.26 * * * \\
{[0.000]}\end{array}$ & $\begin{array}{l}369.13 \\
{[0.114]} \\
\end{array}$ & $\begin{array}{c}138.378 * * * \\
{[0.000]}\end{array}$ \\
\hline $\begin{array}{l}\text { Adj. R-sq.; F-stat } \\
\text { D-W stat; Obs. }\end{array}$ & $\begin{array}{c}0.219 ; 4.15 \\
2.16 ; 540 \\
\end{array}$ & $\begin{array}{c}0.226 ; 4.27 \\
2.17 ; 540 \\
\end{array}$ & $\begin{array}{l}0.27 ; 5.15 \\
2.13 ; 540 \\
\end{array}$ & $\begin{array}{c}0.276 ; 5.28 \\
2.13 ; 540 \\
\end{array}$ & $\begin{array}{c}0.127 ; 2.63 \\
2.09 ; 548 \\
\end{array}$ & $\begin{array}{c}0.135 ; 2.75 \\
2.1 ; 548 \\
\end{array}$ \\
\hline Unemployment Rate & $\begin{array}{c}-0.276^{* *} \\
{[0.017]} \\
\end{array}$ & $\begin{array}{c}-0.076 * * * \\
{[0.000]} \\
\end{array}$ & $\begin{array}{c}-0.265^{* *} \\
{[0.019]} \\
\end{array}$ & $\begin{array}{c}-0.072 * * * \\
{[0.000]} \\
\end{array}$ & $\begin{array}{c}-0.215^{* *} \\
{[0.050]} \\
\end{array}$ & $\begin{array}{c}-0.059 * * * \\
{[0.001]} \\
\end{array}$ \\
\hline $\begin{array}{l}\text { Adj. R-sq.; F-stat } \\
\text { D-W stat; Obs. }\end{array}$ & $\begin{array}{c}0.847 ; 68.24 \\
2.03 ; 585 \\
\end{array}$ & $\begin{array}{c}0.85 ; 69.05 \\
2.03 ; 585 \\
\end{array}$ & $\begin{array}{c}0.838 ; 63.8 \\
2.02 ; 585 \\
\end{array}$ & $\begin{array}{l}0.84 ; 64.6 \\
2.02 ; 585 \\
\end{array}$ & $\begin{array}{c}0.887 ; 95.85 \\
2.02 ; 594 \\
\end{array}$ & $\begin{array}{c}0.89 ; 95.95 \\
2.01 ; 594 \\
\end{array}$ \\
\hline $\begin{array}{l}\text { Poverty Rate } \\
\text { Yr = 1993, 1995, 1997-2005 }\end{array}$ & $\begin{array}{c}-0.276 \\
{[0.508]} \\
\end{array}$ & $\begin{array}{c}0.028 \\
{[0.573]} \\
\end{array}$ & $\begin{array}{c}-0.276 \\
{[0.508]} \\
\end{array}$ & $\begin{array}{c}0.028 \\
{[0.573]} \\
\end{array}$ & $\begin{array}{c}0.229 \\
{[0.349]} \\
\end{array}$ & $\begin{array}{c}0.186 * * * \\
{[0.000]} \\
\end{array}$ \\
\hline $\begin{array}{l}\text { Adj. R-sq.; F-stat } \\
\text { D-W stat; Obs. }\end{array}$ & $\begin{array}{c}0.95 ; 130.5 \\
1.92 ; 315 \\
\end{array}$ & $\begin{array}{c}0.952 ; 131.3 \\
1.90 ; 315 \\
\end{array}$ & $\begin{array}{c}0.95 ; 130.5 \\
1.92 ; 315 \\
\end{array}$ & $\begin{array}{c}0.952 ; 131.3 \\
1.90 ; 315 \\
\end{array}$ & $\begin{array}{c}0.94 ; 163.86 \\
1.12 ; 457 \\
\end{array}$ & $\begin{array}{c}0.948 ; 171.2 \\
1.14 ; 457 \\
\end{array}$ \\
\hline
\end{tabular}

Significance: ${ }^{*} 0.1$ level, ${ }^{* *} 0.05$ level; ${ }^{* * *} 0.01$ level 
Figures

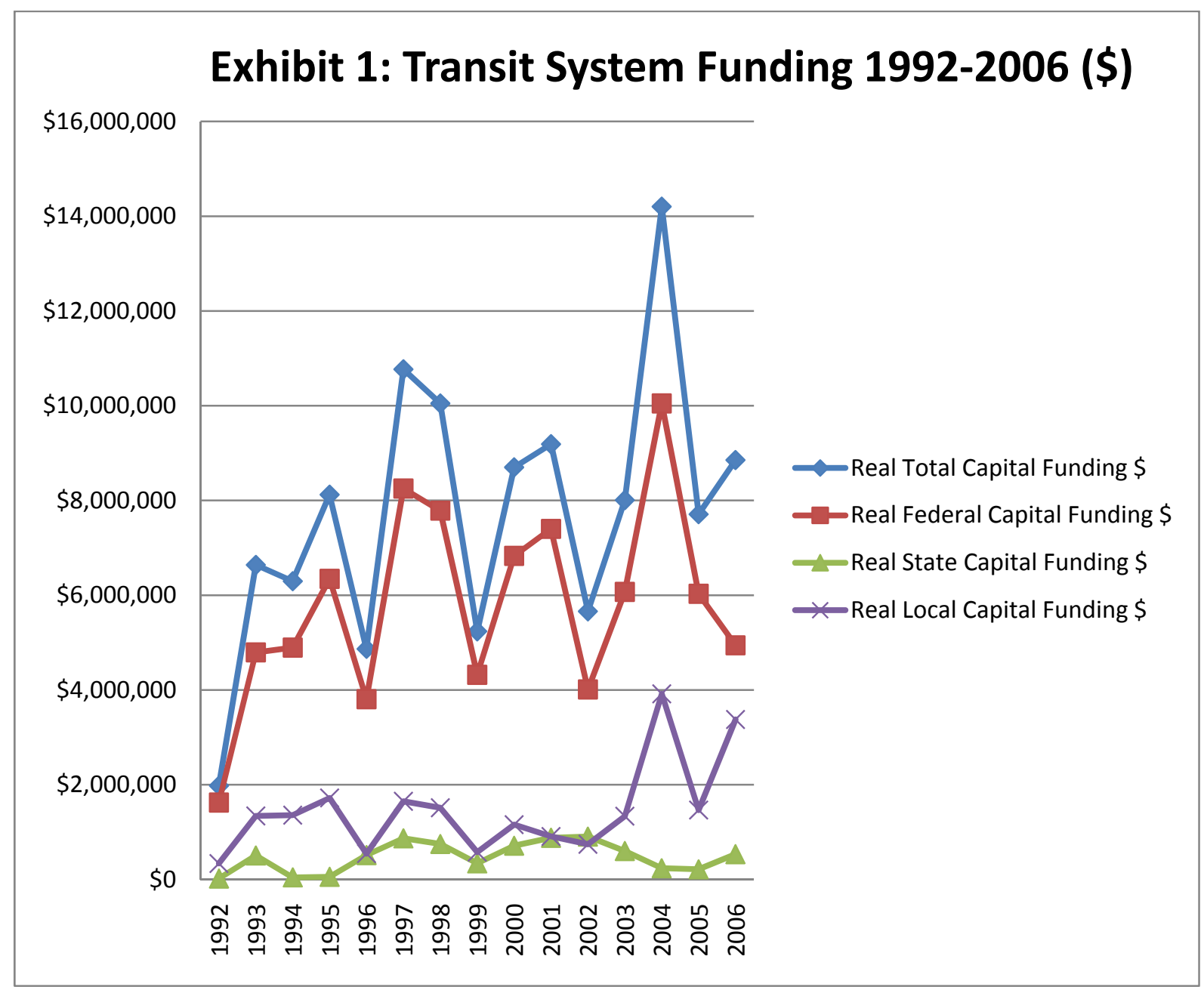

*All dollar values in 1982-84 constant dollars. 


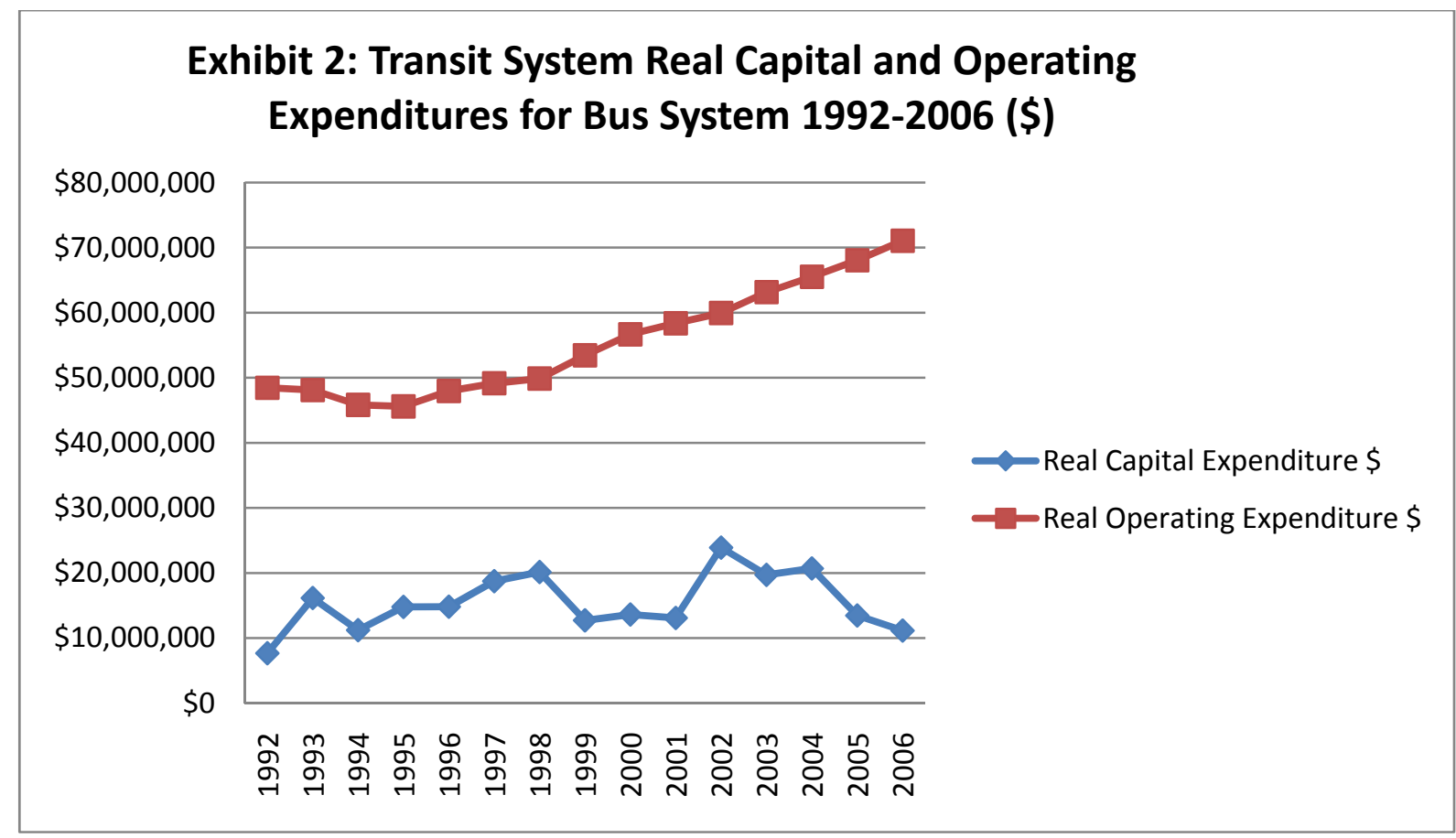

*All dollar values in 1982-84 constant dollars.

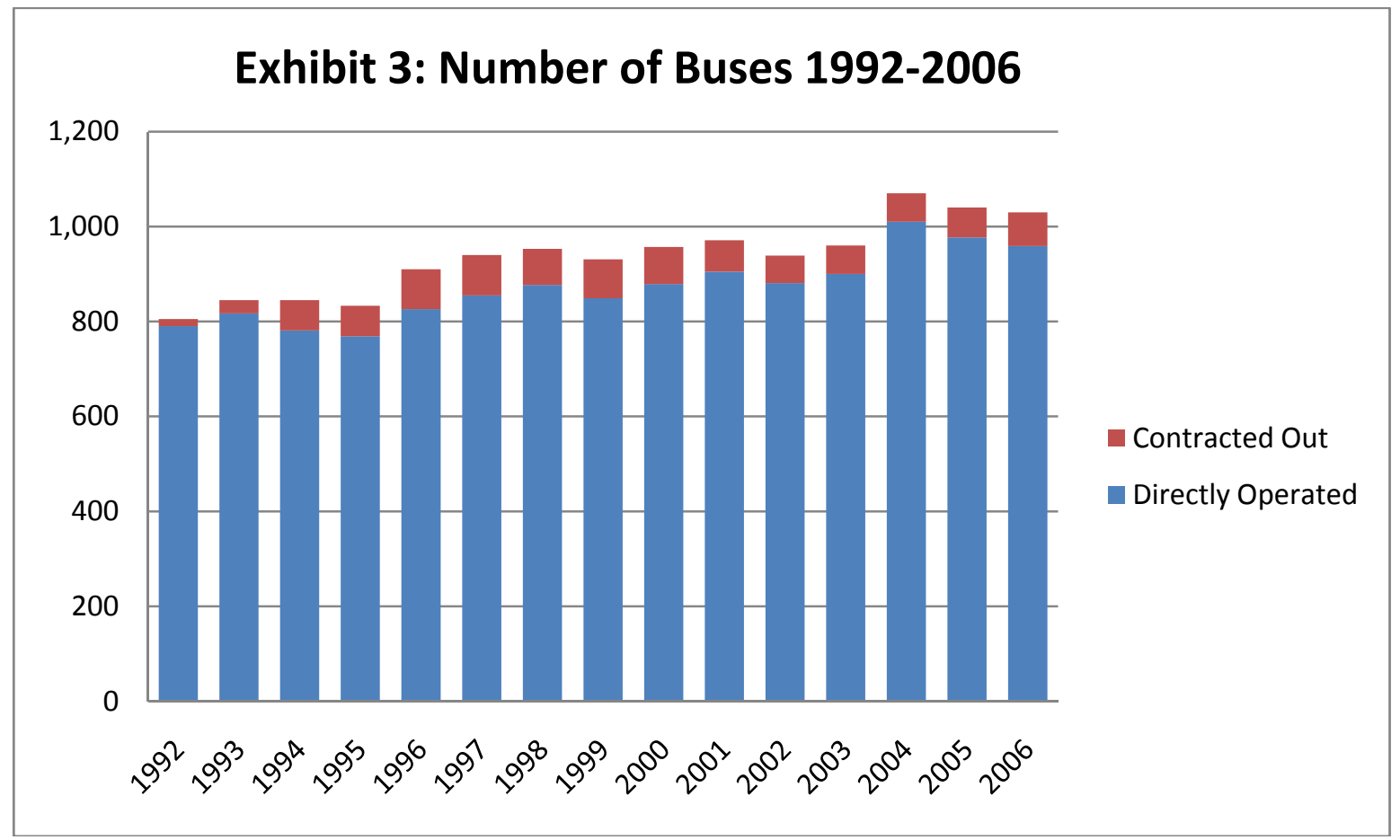




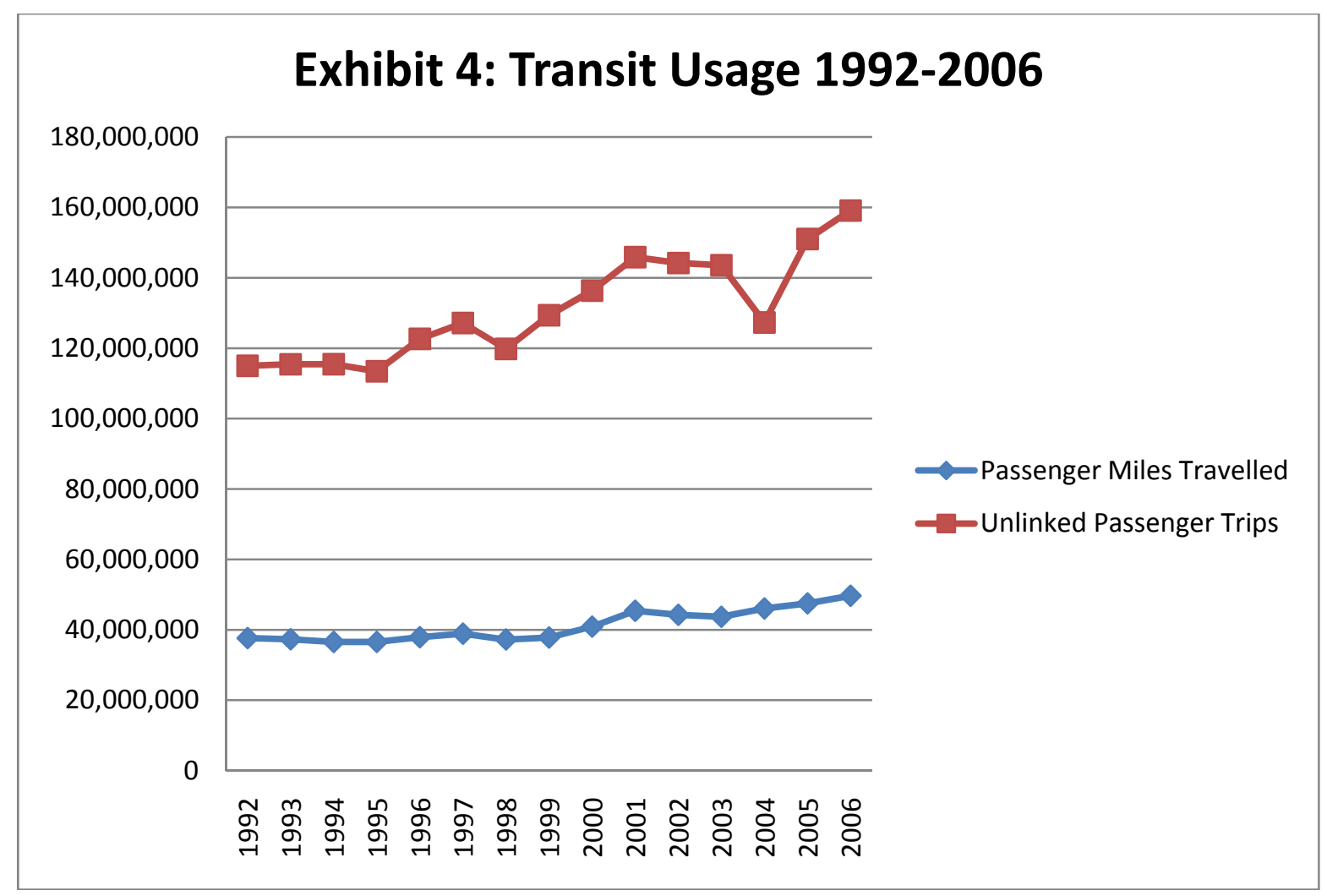




\section{Endnotes}

${ }^{1}$ Since a limited number of variables are available for cities, the county in which the city is located is the focus of analysis in this study.

2 Mass transportation systems in the early part of the $20^{\text {th }}$ century were owned and operated by the private sector. With the advent of the automobile, many of these firms went out of business. See Kyvig, David E. and Marty, Myron A. Getting Around Exploring Transportation History Malabar, FL: Krieger Publishing Co. 2003.

${ }^{3}$ American Public Transportation Association. 2008 Public Transportation Fact Book Washington, D.C. 2008 (Tables 40 and 47).

${ }^{4}$ Ibid.

${ }^{5}$ Some cities opened fixed-route bus systems during the 1992-2006 period. In 1992, 33 counties had bus systems. In 2006, 39 counties had bus systems. Some counties have more than one bus system (there were a total of 47 bus systems in the counties with transit. 